Research, part of a Special Feature on Social Learning in Water Resources Management

\title{
The European Water Framework Directive: How Ecological Assumptions Frame Technical and Social Change
}

\author{
$\underline{\text { Patrick Steyaert }}^{1}$ and $\underline{\text { Guillaume Ollivier }}^{1}$
}

\begin{abstract}
The European Water Framework Directive (WFD) is built upon significant cognitive developments in the field of ecological science but also encourages active involvement of all interested parties in its implementation. The coexistence in the same policy text of both substantive and procedural approaches to policy development stimulated this research as did our concerns about the implications of substantive ecological visions within the WFD policy for promoting, or not, social learning processes through participatory designs. We have used a qualitative analysis of the WFD text which shows the ecological dimension of the WFD dedicates its quasi-exclusive attention to a particular current of thought in ecosystems science focusing on ecosystems status and stability and considering human activities as disturbance factors. This particular worldview is juxtaposed within the WFD with a more utilitarian one that gives rise to many policy exemptions without changing the general underlying ecological model. We discuss these policy statements in the light of the tension between substantive and procedural policy developments. We argue that the dominant substantive approach of the WFD, comprising particular ecological assumptions built upon "compositionalism," seems to be contradictory with its espoused intention of involving the public. We discuss that current of thought in regard to more functionalist thinking and adaptive management, which offers greater opportunities for social learning, i.e., place a set of interdependent stakeholders in an intersubjective position in which they operate a "social construction" of water problems through the co-production of knowledge.
\end{abstract}

Key Words: ecological status; policy analysis; public participation; reference system; social learning; Water Framework Directive.

\section{INTRODUCTION}

The European Water Framework Directive (WFD) is a legally binding document that requires member states (MS) to implement water management measures to achieve good overall quality of European water bodies within $15 \mathrm{yr}$. It results from a joint decision and policy-making process, which provided a bigger role to the European Parliament and strengthened a powerful proecology coalition of environmental NGOs, e.g., European Environmental Bureau, WWF, RSPB, Birdlife. This process gave rise to numerous debates and controversies (Aubin and Varone 2002, Kallis and Buttler 2001, Kaïka and Page 2003a,b) that were finally stabilized by the production of the formal text in October 2000 (Directive 2000/60/EC).
The WFD is built upon two main innovative approaches (see Appendix 1 and Fig. 1 for a brief overview of the WFD): it proposes on the one hand, more integrated ecological definitions of water and, on the other hand, it introduces the notion of public participation for policy implementation. The latter results from a growing awareness that collaborative approaches are needed because of increased complexity in water resources use resulting from increased competition, dissatisfaction with leaving important policy decisions in the hands of agency experts and skepticism about the ability of legalistic agencies to craft viable and long-term solutions (Sabatier et al. 2005). The WFD also encompasses a set of economic principles and measures, which will not be considered in this paper. 
Fig. 1. The main steps and deadlines of the Water Framework Directive (WFD) implementation.

2000: WFD publication

2000-2004: River basin characterization:

Identification and mapping of WB Identification of reference conditions

Pressure and status assessment

Economic analysis of water uses

2004: Definition of Competent Water Authorities

2004-2006: Definition of environmental objectives and issues

2006: Start of monitoring

2007-2008: Public Consultation:

comments on management issues comments on draft copy on River Basin Plan

2009: Final River Basin Plan published

2012: Implementation

2015: All waters at 'good status' except for motivated exemptions

Program of measures evaluation

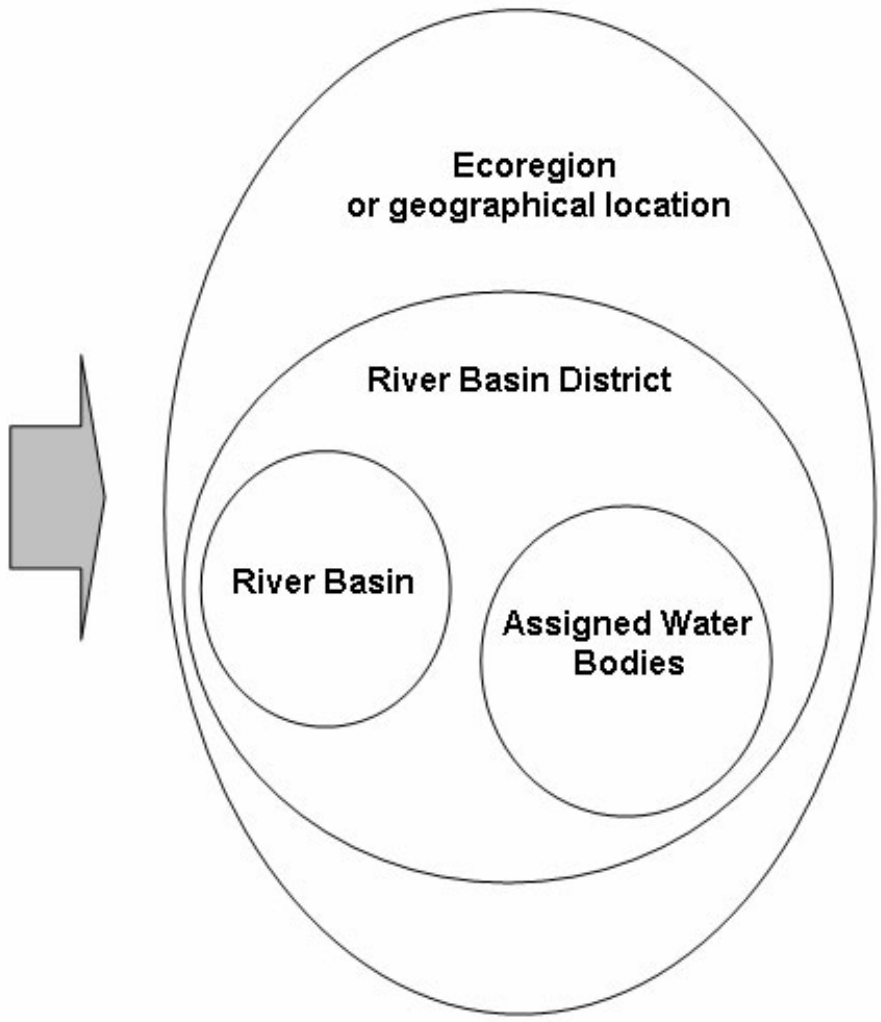

Entities designed during the process
Evidence suggests that when participation is incorporated in a policy, then the quality of participatory processes becomes a key feature for success. The SLIM project (Ison et al. 2004, 2007) in which this study took place has shown these processes, when purposefully managed, (1) can bring interdependent stakeholders to change their understanding, practices, and social relationships to move toward concerted action, and (2) are influenced by a set of key variables among which the policy by itself is an important one (SLIM 2004, Steyaert and Jiggins 2007, in press). In the perspective developed in that work, participatory approaches are more than reaching greater legitimacy of decision making, adaptation to local situations or raising awareness of citizens through information: they place a set of heterogeneous stakeholders in an intersubjective position in which they operate a social construction of water problems and related solutions. Indeed, once a policy is implemented, the vision of the world it conveys interacts with local perceptions and interests leading to a particular translation of the policy's initial goals (Callon 1997). Translation results in, and results from social learning processes, which are key elements in adaptive management (Röling and Wagemakers 1998) and which we define as iterative processes of knowledge co-production, i.e., "knowing," among stakeholders brought into interaction (Steyaert et al. 2007, in press). 
In complex management situations in which "the components and their interactions are changing and can never be quite pinned down" (Snowden 2002:106), we consider social learning is needed to engage various stakeholders in problem formulation allowing stabilized agreements and purposeful action. These processes occur through interactions with others, involve social, cognitive, and emotional dimensions (Illeris 2002) and can be said to take account of Habermas's proposition: “... the paradigm of knowledge of objects has to be replaced by the paradigm of mutual understanding between subjects capable of speech and action" (Habermas 1987:206). In the field of management in which Checkland (1981) states that hard systems are goal seeking, with given or assumed goals, whereas in soft systems the goals themselves are the bone of contention, this perspective raises the question of the role of ecological knowledge in setting the goals. Is it used to force interacting stakeholders to conform in their thinking and doing to problems defined by others in other places? Or is it used to help stakeholders learn about their biophysical environment and adapt their thinking and doing to take most appropriate decisions (cf., the generative dance between knowledge and knowing, Cook and Brown 1999)?

So, the coexistence in the same text of extensive cognitive, theoretical developments in the field of ecology and of requirements for public participation is at the origin of this research. It exemplifies, from our point of view, the tension between substantive and procedural approaches to policy-making processes. In the first case, policies are defined by centralized authorities defining from the beginning objectives to be reached as well as the means needed to achieve them. In the second case, the main part of policy content aims at organizing at territorial level framed social interactions, common working methods, and the formulation of collective agreements (Lascoumes and Le Bourhis 1998). How do these two approaches fit together? Can they be complementary or are they antagonistic? What are the implications of particular ecological visions for promoting social learning processes in participatory designs?

\section{METHODS}

Public policies, even though they often result from a long, complex, and chaotic policy-making process, must at some point stabilize particular understandings apparent in the knowledge and norms that are codified into laws. They are built around a reference system that places them in a scientific and social context (Muller 1995) according to:

- A cognitive dimension, i.e., a knowledge base that provides an understanding of the nature of the world. It describes the world, makes it intelligible, and reduces uncertainty by constructing the reality of ecological, institutional, and social objects and processes. These are the preliminary steps that build a theory upon which we can define our actions, i.e., if X... then Y...;

- A normative dimension, i.e., how the world should be. It relates to the construction and use of values and norms. The values provide an overall framework for public action by setting the limits of what is good, bad, desirable or not;

- An instrumental dimension, i.e., what should be done to get closer to the norm in terms of instruments and procedures. It proposes timelines, action rules, decision-making procedures, methods, and instruments to achieve policy goals.

Cognitive and normative dimensions are often difficult to distinguish (Larrère 1997), whereas the instrumental one makes explicit references to means, procedures, measures, etc. Knowledge in a prescriptive context, like a policy, provides guidelines for action and therefore acquires a normative character. Theses norms rely on references to either higher-level norms such as equality or justice or to social, psychological, or technical knowledge (Troper 2000). Despite this difficulty, we have tried to discriminate among these three categories within the Water Framework Directive (WFD) text (Ollivier 2004) by paying attention to:

- Text referring to knowledge, presented in an affirmative, descriptive, or explanatory form, i.e., "something is..." These are supported by stabilized facts and concepts;

- Normative statements characterized by modal operators such as "it is necessary to," "one must," "one can," and "it is desirable 
to," which reveal their prescriptive character, i.e., "something ought to be..." These are generally supported by principles and obligations to act;

- Text items describing procedures, methods and instruments that are proposed to achieve the stated objectives.

We have used these elements to qualitatively assess to what dimension each article and annex mainly refers. We have also grouped these pieces of text together in meaningful topics, e.g., water body characterization, ecological status, reference conditions, etc., in order to: (1) locate uncertainties and contradictions between statements, (2) assess their relative normative weight, and (3) identify the values and schools of thought to which the norms and knowledge refer. In the result section that follows, we first provide an overview of the balance of the entire text, which will show that ecological developments occupy the most part of the WFD. We will then explore how that ecological dimension is built and supported by policy instruments before discussing these elements in regard of social learning and experts' involvement in policymaking.

\section{SOME KEY ELEMENTS OF CONTENT ANALYSIS}

\section{Balance of the Water Framework Directive (WFD) among the three dimensions}

The introductory part of the Water Framework Directive (WFD) comprises 53 statements (s.) referring to previous decisions and treaties and exposing general principles upon which the policy is built. This section is normative by essence. Twenty-six articles (ar.) and 11 associated annexes (an.) follow, developing in more detail the various elements of the policy. A rough classification of these articles and annexes by number of words (Table 1) shows the great importance of cognitive developments $(59 \%)$ in comparison to normative and instrumental ones, i.e., $17 \%$ and $24 \%$, respectively. Articles are mainly normative and instrumental, i.e., $41 \%$ and $44 \%$, whereas annexes are mainly cognitive, i.e., $88 \%$.

Some key principles framing the whole content of the WFD are set in the introductory section and further developed in articles:
- "water is not a commercial product like any other but, rather, a heritage which must be protected, defended and treated as such" (s.1);

- "sustainable management and protection of freshwater resources" (s. 3) will be achieved by the implementation of an "integrated Community policy," (s.9, 18) which will be based on the prudent and rational use of natural resources and on principles such as the precautionary principle, preventive action, rectification of environmental damage and payment of costs by polluters (s. 11);

- improving the aquatic environment primarily concerns the quality of water, which is influenced by quantitative aspects (s.19);

- common definitions of the status of water, using technical specifications ensuring a coherent community approach (s.49), are needed and environmental objectives must be set to ensure good status (s.25, 26) which will be achieved through the political coordination of decisions (s.35) and through ecological coordination of measures at the river basin scale (s.36);

- finally, implementation may be flexible in regard to timetables and costs, (s.31) and derogations and exemptions to the general model may be set. In all cases, all these should be made on the basis of appropriate, evident, and transparent criteria.

In the light of these main principles, it appears the WFD supports a specific water quality model and another picture of it can be given (Fig. 2): most of its cognitive and normative dimensions concern water body characterization and water status monitoring in order to achieve the fixed standard of "good status". In other words, the WFD is clearly dominated by ecological knowledge and norms that constitute the main part of its substantive developments whereas other considerations like public participation or social and economic aspects of implementation are poorly developed and only normatively defined. What is the ecological perspective supported by the WFD and how is it instrumented? 
Table 1. An overview of the general balance of the Water Framework Directive (WFD) articles and annexes among cognitive, normative, and instrumental dimensions.

\begin{tabular}{|c|c|c|c|}
\hline $\mathbf{N}^{\circ}$ & Titles of articles and annexes & $\begin{array}{c}\text { Number of } \\
\text { words }\end{array}$ & Dominant dimension \\
\hline
\end{tabular}

\begin{tabular}{|c|c|c|c|}
\hline 1 & Purpose & 297 & Normative \\
\hline 2 & Definitions & 1.601 & Cognitive \\
\hline 3 & Coordination of administrative arrangements within river basin districts & 487 & Instrumental \\
\hline 4 & Environmental objectives & 1.972 & Normative \\
\hline 5 & $\begin{array}{l}\text { Characteristics of the river basin district, review of the environmental } \\
\text { impact of human activity, and economic analysis of water use }\end{array}$ & 147 & Instrumental \\
\hline 6 & Register of protected area & 139 & Instrumental \\
\hline 7 & Waters used for the abstraction of drinking water & 225 & Normative \\
\hline 8 & Monitoring of surface water status, groundwater status, and protected areas & 206 & Normative \\
\hline 9 & Recovery of costs for water services & 367 & Normative \\
\hline 10 & The combined approach for point and diffuse sources & 262 & Normative \\
\hline 11 & Programme of measures & 1.541 & Instrumental \\
\hline 12 & Issues which can not be dealt with at Member State level & 87 & Instrumental \\
\hline 13 & River basin management plans & 307 & Instrumental \\
\hline 14 & Public information and consultation & 238 & Instrumental \\
\hline 15 & Reporting & 193 & Instrumental \\
\hline 16 & Strategies against pollution of water & 1.074 & Normative \\
\hline 17 & Strategies to prevent and control pollution of groundwater & 275 & Instrumental \\
\hline 18 & Commission report & 385 & Instrumental \\
\hline 19 & Plans for future Community measures & 111 & Instrumental \\
\hline 20 & Technical adaptations to the Directive & 116 & Instrumental \\
\hline 21 & Regulatory committee & 72 & Instrumental \\
\hline 22 & Repeals and transitional provisions & 509 & Instrumental \\
\hline 23 & Penalties & 34 & Normative \\
\hline 24 & Implementation & 110 & Instrumental \\
\hline 25 & Entry into force & 33 & Instrumental \\
\hline
\end{tabular}


26

Addresses

Total number of articles' words and rate of dimensions

I Information required for the list of competent authorities

II No title: water body typology

III Economic analysis

IV Protected areas

V No title: definition, monitoring and classification of the water status

VI Lists of measures to be included within the programmes of measures

VII River basin management plans

VIII Indicative list of main pollutants

IX Emission limit values and environmental quality standards

XI No title: ecoregion maps

Total number of annexes' words and rate of dimensions

Total number of words and rate of dimensions
26

Instrumental

10.814

$$
\mathrm{C}=15, \mathrm{~N}=41, \mathrm{I}=44
$$

239

2910

Instrumental

145

222

11612

333

898

135

109

125

Cognitive

Normative

Instrumental

Cognitive

Instrumental

Instrumental

Cognitive

Normative

Cognitive

16.728

$\mathrm{C}=88, \mathrm{~N}=2, \mathrm{I}=10$

27.542

\section{A new water paradigm strongly defined and instrumented}

The ecological vision adopted in the WFD considers human activities as a source of disturbance preventing water bodies from reaching their reference status. Consequently, the WFD recommends that humans assume their responsibility toward the aquatic ecosystem by reducing their impact on it in order to get closer to an ideal pristine nature. The new water paradigm, developed under this perspective, is no longer cause-related but proposes a more integrated approach to water management and considers that surface water is a "life milieu." Whereas water bodies are "containers" of chemical and physical elements, surface waters also constitute biological aquatic ecosystems, which influence the functioning of terrestrial ones, and groundwater influences surface waters both qualitatively and quantitatively. This change increases considerably the level of complexity covered by tackling numerous ecological interdependencies, e.g., between aquatic and terrestrial ecosystems, between ground and surface waters, between quantity and quality of water, and among chemical, physical, and biological components.

Building upon this new paradigm, the Directive frames the way member states must identify and classify their water bodies (an. II), assess their status (an. V) and set the environmental objectives (ar. 4). Water status is defined by several terms depending on water body types, i.e., chemical, quantitative, and ecological. The most developed part of the text concerns the ecological status of surface waters and the determination of type reference conditions. Ecological status is defined as an "expression of the quality of the structure and functioning of aquatic ecosystems associated with surface waters" (ar. 2.21). The use of biological elements prevail in characterizing ecological status and put forward the taxonomic structure of ecosystems through the assessment of composition and abundance of main species categories, e.g., aquatic flora, benthic invertebrate fauna, fish fauna, phytoplankton, etc. This perspective dedicates its quasi-exclusive attention to compositionalism. This current of 
Fig. 2. Categorization of articles and annexes by number of words and rate.

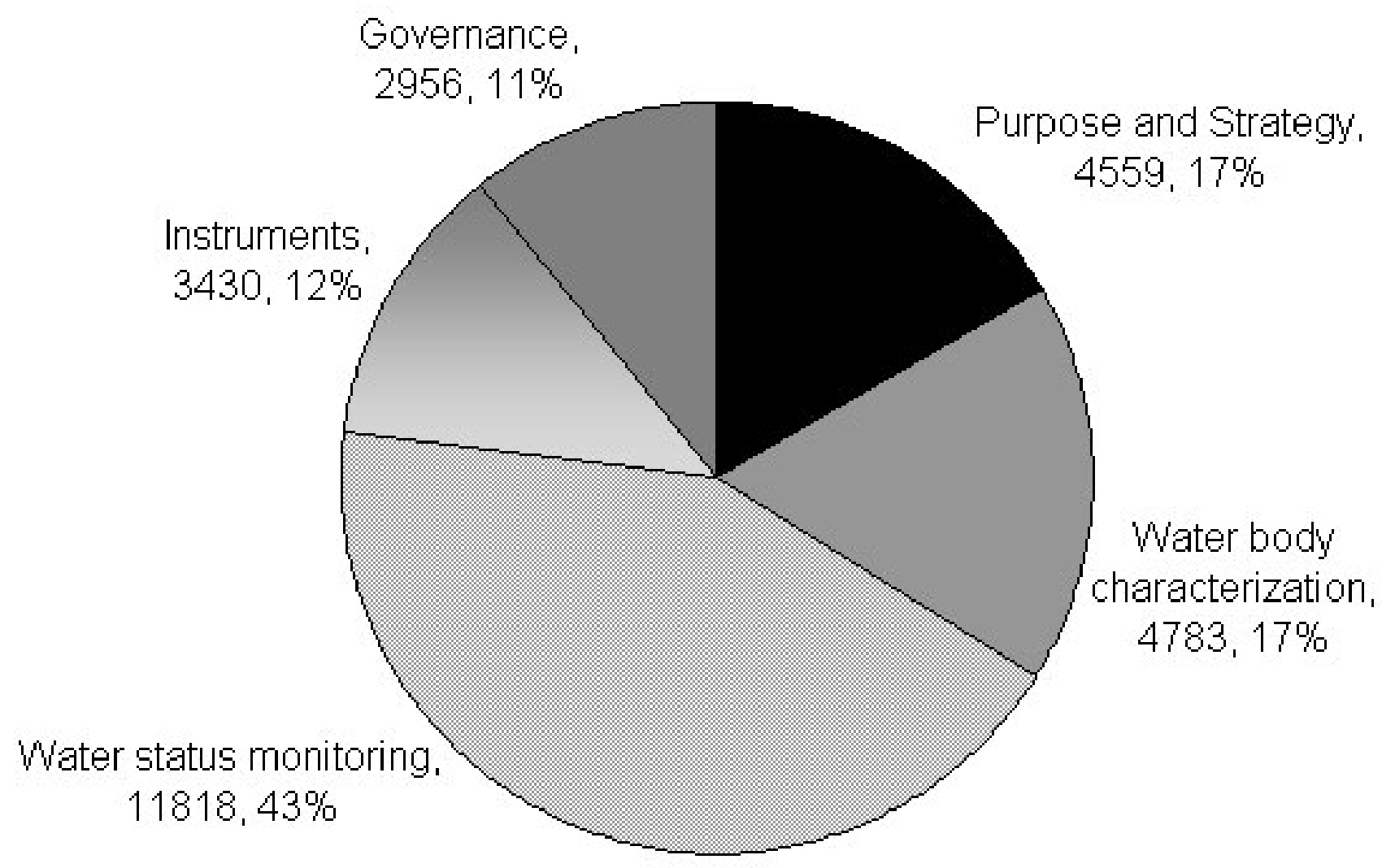

thought, that we will discuss later on, understands nature in terms of the integrity of biotic communities of ecosystems and considers Homo sapiens as separate from nature (Callicott et al. 1999; also discussed in Hunter (2000) and Robertson and Hull (2001)). The main action principle resulting from this vision consists in bringing surface water statuses from their current state, which represent the poorer of ecological, chemical, and quantitative statuses, to their good state, in which the values of biological elements show low levels of distortion resulting from human activity. To support that action principle, the notion of type specific reference conditions corresponding to the high status in which the values of physical-chemical, hydro-morphological, and biological elements show no or very slight alterations due to human activity becomes central, because it must allow identify and quantify distortions due to anthropogenic pressures and define what is good.

Three methods may be used by MS to establish the ecological type reference conditions for each water body type (an.II.1.3 and an. V):

- $\quad$ in reference to a network of high status sites providing "a sufficient level of confidence about the values for the reference conditions;" 
- $\quad$ by using "predictive models or back-casting methods ... which shall use historical, palaeontological and other available data;"'

- or, when it is not possible to use these methods, by the use of expert judgments to establish such conditions.

The determination of these reference conditions, in particular the numerical values of the quality elements listed, is a key issue in implementing the WFD (see for example the STAR project, Furse et al. 2006). On the one hand, the three options offered by the WFD recognize it will be difficult to find undisturbed water bodies and to determine the right values. On the other hand, as environmental objectives to be reached are strongly defined, the notion of distortion will probably become heavily debated and contested. This was still the case in building up the policy, which has led to the introduction of numerous derogations and exemptions.

\section{Derogations are institutionalized but do not challenge the model}

Indeed, the general ecological model adopted was contested mainly by MS and professional lobbies wanting to introduce a more utilitarian perspective on water (Kaïka and Page 2003a). Contestation has led to define a set of derogations and exemptions (ar.4.3 to 7): identification of artificial and modified water bodies, extension of phased achievement of objectives, achievement of less stringent environmental objectives, temporary deterioration in the status of water bodies and finally failure to achieve good status for human development reasons. The main criteria advanced are:

- disproportionate costs or technical unfeasibility, for example to replace, by changes of hydromorphological characteristics, the beneficial objectives served by artificial or modified water bodies;

- unforeseen or exceptional natural causes, e. g., flood, drought and major forces or accidents leading to temporary deterioration;

- $\quad$ outweighing of the benefit of achieving good status by the benefits provided by new modifications or alterations of water bodies to human health, human safety or to sustainable development.
The definition of artificial and heavily modified water bodies (ar. 8 and 9) led to the transformation of the notion of good ecological status into that of good ecological potential and to express objectives to be reached in terms of highest possible status, least possible changes to good status or even less stringent environmental objectives. However, the notion of ecological potential is not theoretically built per se, i.e. leading to a revision of the model supported by the WFD, but in regard of the typereference conditions. Besides the requirement to precisely set out the reasons for modifications or alterations, member states have to use the same standardized monitoring system. For example, the biological conditions of these water bodies must be established with "the values of relevant biological quality elements which reflect, as much as possible, those associated with the closest comparable surface water body type, given the physical conditions which result from the artificial or heavily modified characteristics of the water body" (an.V.1.2.5). These derogations and exemptions mainly reveal the difficulty in integrating human development perspectives into the ecological model adopted. They do not change fundamentally the ecological visions of some of the WFD conceivers but have been added as a result of the power game that took place during the policy-making process. The Directive reflects "a political struggle between two views of water's value" and results in "an hybrid between communitarian and utilitarian concerns" (Ison 2007:1). As a consequence, the WFD embodies a series of internal contradictions between stakeholder engagement, if it has to include defining priorities to be meaningful, economic analysis claiming to be able to determine the optimal outcome, and the fixed standards for defining environmental objectives (Green and FernandezBilbao 2005). How will these contradictions be interpreted by policy implementers but also, and more importantly, once implemented, how will it be assessed by policy conceivers? This relates to the legally binding character of the WFD supporting its both substantive and procedural dimensions.

\section{The role of public participation as stated in the Directive}

The legally binding character of the WFD relates to the obligation to transpose it into national laws before end of 2003 and to designate "Competent Water Authorities" (ar. 3) for implementation. Information required about these authorities (an. I) insists on their geographical coverage, legal status, 
responsibilities and institutional relationships with other authorities. Competent authorities must ensure coordination among all stakeholders and bodies concerned with water management in order to draft up river basin management plans. These plans must provide information about all points listed in annex VII, which mainly correspond to all obligations that have been set. One point of the list (an. VII. 9) concerns a summary of measures adopted to involve the public and of the consequences of these measures on management plan modification. Indeed, the WFD insists in article 14 on the active involvement of all interested parties in the production, review and updating of the river basin management plans. But what does active involvement mean precisely? As stated in the policy, the way chosen to involve citizens is mainly based on information and consultation and very few methodological indications are given to ensure public participation compared to the ecological content of the Directive ${ }^{[\dagger]}$. For example, the WFD states in general terms MS shall "publish and make available for comments to the public a timetable and a work program, (...) an interim overview of the significant water management issues, (...) draft copies of the management plan" (ar.14). For each step, the public has at least 6 mo to comment in writing on those documents and, on request, access shall be given to background documents and information.

In contrast with the narrow ecological definitions adopted the very broad definitions of governance procedures may lead to various interpretations and adoptions in European Union (EU) countries. Depending on institutional and political contexts, competent authorities may be national bodies, e.g., the Environment Agency in England, or more local ones, e.g., hydro-geographical water agencies in France, and public participation may be limited to the involvement of legally mandated agencies and experts as well as extended to broader audiences. In some way, the WFD leaves to MS the responsibility to determine how they will organize implementation to achieve the goals. In our perspective, that freedom left to MS as well as all uncertainties introduced by derogations and exemptions could well become the most performative part of the WFD. For example, Orr et al. (2007) show how the Environment Agency in England and Wales being solely accountable to the EC for reporting on progress toward implementation has challenged its current arrangements for stakeholder engagement at various scales, i.e., "encourage people to discuss and get involved in work on the water environment in ways that make sense to them "(Orr 2007:342), and its catchments science program, i.e., stronger focus on interdisciplinary working and more effective interface with river basin management emphasizing processes over outcomes. Are these implementation experiences constrained by the knowledge base of the WFD, and will they challenge its fixed ecological standards? This is what we will discuss now in a prospective manner.

\section{DISCUSSION}

As stated by Ost (2003), a law is accustomed to use definitions with clear outline, stable criteria, and boundaries, which segment reality. The WFD links together a huge number of heterogeneous elements, i.e., natural, technical, and social objects, embodied in knowledge, norms, and instruments. Despite the fact, which can be confusing, our content analysis, which is limited to the ecological dimension, shows that the WFD is built around a consistent reference system made of strong but particular ecological assumptions. What can we learn from it about experts and scientists involvement in policy-making processes? How do substantive developments support the visions conveyed by the policy and how could they influence implementation?

\section{Becoming aware of our traditions of understanding}

Regarding environmental issues like water preservation, policies propose new or revised conceptions of the relationship between the natural and the social. In the case of the WFD, the use of particular assumptions result from the large involvement of NGOs in the policy-making process, and particularly their experts in aquatic ecology asking for greater incorporation of scientific knowledge into the policy (Aubin and Varone 2002, Barraqué 2003). By incorporating natural sciences into policies, these experts carry a huge responsibility in the determination of how humans shall behave. First, we argue that this responsibility cannot be avoided and second, it implies that scientists need to become more aware of their traditions of understanding (Ison and Russell 2000) and their consequences for policy implementation. Indeed, ecological epistemologies proceed from reduction of complexity in understandable subsets and, as noticed by Hilderbrand et al. (2005:2), 
"failure to recognize the limitations and tacit assumptions can lead to failures because of the overapplication of over-simplified concepts to complex systems."

Science and society are facing issues in which facts are uncertain, values in dispute, stakes high, and decisions urgent (Funtowicz and Ravetz 1999). In that context, ecological scientists like others may have some fear of taking sides on value-laden issues and can ask to distinguish between "setting reference conditions, which is a scientific process," and goal-setting, which is part of a political process (see EurAqua recommendations 2001:2). We argue this position is not tenable. Once scientists and experts are asked to define what reality is, this distinction becomes impossible because knowledge carries implicit values and worldviews: what they say and know cannot be distinguished from what they think reality ought to be. By excluding human activities to build up the reference conditions of water, experts frame the way goals may be set, e.g., they give advantage to the model of pristine nature they defend.

The underlying ecological assumptions of this model are actually a controversial stance in ecological science (Deléage 2001). Restoration of ecological status toward a unique biological typespecific reference does not take into account the potential existence of many succession trajectories toward many sustainable domains, i.e., multiple stable states (Holling 1973, Gunderson 2000) or even toward none (Lepart 1997, Müller 1997). Similarly, postulating taxonomic structure characterizes ecological disturbances and functions has been strongly questioned: for instance, species are substitutable to ensure a similar function (O'Neil 2001), and the signification of taxonomic stability is questioned in regard of complex and diverse systems (Lepart 1997). In light of these statements, the European Network of Freshwater Research Organizations tried to offer an alternative and redefined reference conditions as corresponding to "a situation with hydro-morphological and physicochemical regime sustaining a healthy ecosystem functioning with natural biodiversity" (EurAqua 2001:1). Their definition aims to take into account natural, spatial, and temporal variations of phenomena (Charvet 1999) and supports more functionalist thinking (Callicot et al. 1999) referring to notions such as biological traits or ecosystem health (Wasson et al. 2003).
Policy makers are not necessarily aware of the various schools of thought impeding ecological sciences, as scientists are not always aware of and do not necessarily want to make explicit what values they defend. Whilst realizing that a policy is the result of institutional settings and social asymmetries, we argue that the lack of shared understanding of these values and assumptions forces policy building into areas of conflict resolution, negotiation, and compromise. This is exemplified by the exemption regimes of the WFD, which result from the fight between communitarian and utilitarian perspectives during the policymaking process. These exemptions could lead to unexpected consequences: as noticed by Greenpeace (Lanz 1998), 90\% of European water bodies could be under these exemption regimes. Reinforcing the knowledge base of policies, as asked for by the European Environmental Agency (2003), which considers data, information, and knowledge must inform all steps of the policy-making cycle, will not change that situation. A complementary policymaking process is needed which could be based on the systematic and systemic inquiry of scientist and policy conceivers' assumptions and understandings. For example, exploring traditions of understanding leading to define environmental objectives in terms of ecological status in the field of compositionalism, or ecosystem health, referring to functionalism, could allow policy makers to better understand how social and technical changes are conceived under both perspectives and what role science could or should play in enabling these changes.

\section{A dominant substantive approach based on an "epistemology of possession" of knowledge}

Defining ecosystems in terms of status will lead to the extensive use of descriptive knowledge and to the implementation of instruments and tools that must provide the qualitative and quantitative data that corresponds to pre-existing categories. Most of the values are unknown, but the water problem is defined through the notion of undisturbed water body type, and the environmental objectives and related ecological descriptors are given. The consequence of this substantive policy approach, observable in numerous implementation situations, is the important mobilization of scientists, experts, and institutional bodies to provide the most appropriate response to the policy (see for example, Noble and Cowx 2002, Buffagni and Furse 2006). The cognitive basis of the WFD demonstrates how 
knowledge is supposed to support the definition, monitoring, and assessment of water management plans. This movement relates to what Cook and Brown (1999) have named an "epistemology of possession" of knowledge, when knowledge in its stabilized forms is considered to be able to circulate from one place to another and to be used as such for innovation. Policy makers at the EU level implicitly refer to that epistemology when they ask for more knowledge to be produced and for better integration between science and policy (Quevauviller et al. 2005).

Whereas participatory approaches are considered by the WFD itself as an essential ingredient for success, this increased reliance on science and expertise may cause the social exclusion of some stakeholders: those whose skills and knowledge are not sufficient to understand the law. As in other similar situations, such as the implementation of Natura 2000 (Steyaert et al. 2007), participation has more to do with the social acceptability of the policy rather than obtaining a genuine commitment from stakeholders via a process of change of their understandings and water management practices able to address situated water problems. It seems the use of economic principles and tools like costeffectiveness and cost-benefit analysis goes the same way: they are supposed to objectively determine the appropriate decisions on measures that have to be taken. These methods are looking for ecological efficiency and do not take into consideration equity issues, macroeconomic effects, or even sustainability aspects (Messner 2006).

We argue the dominant way of thinking that underpins the whole WFD is based on that epistemology of possession, which also incorporates a transfer of knowledge model, in which problems are considered as known and knowable and in which the knowledge base made of ecological monitoring, and economic rationality must serve changes identified as needed. This epistemology is antagonistic to public participation and social learning in which the latter results from processes that bring interacting stakeholders to build the issues and, in so doing, to produce appropriate knowledge (Steyaert and Jiggins, in press). Policies or policy implementation that favors social learning needs to think about resource management not in terms of a given status to reach but in more dynamic terms like in adaptive management where "it is acknowledged that managed resources will always change as a result of human intervention, that surprises are inevitable, and that new uncertainties will emerge" and where "policies must satisfy social objectives, but also must be continually modified and flexible for adaptation to these surprises" (Gunderson 1999:1, Olsson and Folke 2004). From this perspective, the notion of ecosystem health, or more broadly the concepts referring to functionalist thinking, offers greater opportunities for stakeholders' involvement. It requires people to answer the question of what a healthy ecosystem functioning is. In that case, ecological knowledge will not be used to set the goals in terms of stabilized states but must help stakeholders make choices on what kind of water uses and management practices are acceptable to them and can ensure the resilience and reversibility of ecological processes in context. Pragmatically, the WFD offers this alternative by introducing the notion of ecological potential related to artificial or heavily modified water bodies. Although seen by most of its conceivers in the field of environmental protection as a risk of failure (Lanz 1998), it could well become the most appropriate way of implementation offering a more procedural approach allowing learning processes to occur and stakeholder commitment to the policy to develop.

Finally, we could also argue policy uncertainties are needed to provide leeway for intervention. Indeed, uncertainties mostly explain framing and overwhelming processes (Callon 1997) during policy implementation leading respectively to definition of collectives of actors and objects such as competent authorities, water bodies, or water status in response to the WFD framework, and to explore new ones generating controversy and new uncertainties, i.e., those that will emerge during implementation. This dynamic is needed so as to involve stakeholders in new thinking and doing because the reduction of these uncertainties will result from the management of social interactions at territorial level making questionable the questions around water. In these situations, research conducted by SLIM (Steyaert and Jiggins, in press) indicates social learning can be used as a purposeful policy option to manage social interactions and to build an adaptive frame to allow and manage overwhelming processes. The success of these processes is mainly linked to the existence of conducive institutional arrangements, to the key role of process managers acting as facilitators and to the use and production of knowledge such as information communication tools (ICT) as means for the exploration of controversies and uncertainties (Tippet et al. 2005). 


\section{CONCLUSION}

It is not our aim to contest the legitimacy of scientific knowledge or the practices of policy makers in setting political goals. But our own tradition of understanding resulting from our research experience in the field of natural resource management (Steyaert et al. 2007) has brought us to consider knowledge more in its potential use to enable social and technical change rather than in its ability to prescribe change. From this perspective, the nature of knowledge as well as its use in action becomes a key element for understanding technical and social change. Facing complex and uncertain management situations, stakeholders have to learn about their natural and social environment and to change their understandings in order to increase their capacity to act in more sustainable ways. We consider public participation resulting in social learning processes creates the conditions for these changes to happen.

The Water Framework Directive (WFD) states that active involvement of the public is needed but draws on very broad and traditional understandings to define what its role should be. In contrast, it builds a very consistent frame in supporting the ecological visions to be promoted. By speaking of water in terms of status and by setting the goals in reference to undisturbed conditions, we argue that the substantive part of the WFD leaves little space for stakeholders to commit themselves to the political purposes and uses a huge amount of expertise to feed the monitoring and assessment requirements. There is no doubt that these substantive developments could serve some performative function in revealing to stakeholders how their own bodies of water measure up against the standard of undisturbed conditions. However, we argue that the WFD, by setting environmental objectives through the fixed standard of "good ecological status," is at risk of losing its meaningful character. More functionalist thinking is needed to allow interacting stakeholders to identify water problems and issues, make feasible choices, and become involved in social learning and adaptive management. The strong ecological standards proposed will no doubt be contested and revised as a result of these adaptive processes. This raises the question of how the WFD will be adapted to take stock of the various experiences gained trough its implementation.
Responses to this article can be read online at:

http://www.ecologyandsociety.org/vol12/iss 1/art25/responses/

\section{Acknowledgments:}

The research undertaken for this paper was carried out as part of the SLIM project (Contract no EVK1-2000-00695SLIM) coordinated by R. L. Ison, and funded by the European Commission. We would like to extend thanks to Marco Barzman who translated the Case Study Monograph on which this paper is largely based.

\section{LITERATURE CITED}

Aubin, D., and F. Varone. 2002. European water policy: a path toward an integrated resource management? EUWARENESS. AURAP-UCL, Louvain-La-Neuve, France.

Barraqué, B. 2003. Les enjeux de la Directive cadre sur l'eau de l'Union Européenne. III World Water Forum. Osaka, Japan.

Buffagni, A., and M. Furse. 2006. Intercalibration and comparison: major results and conclusions from the STAR project. Hydrobiologia 566:357-364.

Callicott, J., L. Crowder, and K. Mumford. 1999. Current normative concepts in conservation. Conservation Biology 13(1):22-35.

Callon, M. 1997. Exploration des débordements et cadrage des interactions: la dynamique de l'expérimentation collective dans les forums hybrides. Pages 57-98 in C. Gilbert and I. Bourdeaux, editors. Information, consultation, expérimentation: les activités et les formes d'organisation au sein des forums hybrides, Séminaire du Programme Risques Collectifs et Situations de Crise, CNRS, Paris, France.

Charvet, S. 1999. Intégration des acquis théoriques récents dans le diagnostic de la qualité écologique des cours d'eau à l'aide des bioindicateurs invertébrés. Thesis. Université Claude Bernard Lyon 1, Lyon, France.

Checkland, P. 1981. Systems thinking, systems practice. John Wiley, Chichester, UK. 
Cook, S. D. N., and J. S. Brown. 1999. Bridging epistemologies: the generative dance between organizational knowledge and organizational knowing. Organisation Science 10(4):381-400.

Deléage, J. -P. 2001. Une histoire de l'écologie. Le Seuil, Paris, France.

EurAqua. 2001. Good ecological status: reference conditions for surface waters. European Network of Fresh Water Research Organizations, 8th Scientific and Technical Review, 1 October 2001, Helsinki, Finland.

European Environment Agency (EEA). 2003. EEA Strategy 2004-2008. Office for Official Publications of the European Communities, Luxembourg, Luxembourg.

Funtowicz, S., and J. Ravetz. 1999. Post-normal science: an insight now maturing. Futures 31 (7):641-646.

Furse, M., D. Hering, O. Moog, P. Verdonschot, R.K. Johson, K. Brabec, K. Gritzalis, A. Buffagni, P. Pinto, N. Friberg, J. Murray-Bligh, J. Kokes, R. Alber, P. Usseglio-Polatera, P. Haase, R. Sweeting, B. Bis, K. Szoszkiewicz, H. Soszka, G. Springe, F. Sporka, F., and I. Krno 2006. The STAR project: context, objectives and approaches. Hydrobiologia 566:3-29.

Green, C., and A. Fernandez-Bilbao. 2006. Implementing the Water Framework Directive: how to define a "competent authority"? Journal of Contemporary Water Research and Education 135:65-73.

Gunderson, L. H. 1999. Resilience, flexibility, and adaptive management: antidotes for spurious certitudes? Conservation Ecology 3(1):7 [online] URL: http://www.consecol.org/vol3/iss 1/art7/.

Gunderson, L. H. 2000. Ecological resilience: in theory and application. Annual Review of Ecology and Systematics 31:425-439.

Habermas, J. 1987. The philosohical discourse of modernity. Polity Press, Cambridge, UK.

Hilderbrand, R. H., A. C. Watts, and A. M. Randle. 2005. The myths of restoration ecology. Ecology and Society 10(1):19. [online] URL: http:/ /www.ecologyandsociety.org/vol10/iss1/art19/.
Holling, C. S. 1973. Resilience and stability of ecological systems. Annual Review of Ecology and Systematics 4:1-23.

Hunter, M. 2000. Refining normative concepts in conservation. Conservation Biology 14(2):573.

Illeris, K. 2002. The three dimensions of learning: contemporary learning theory in the tension field between the cognitive, the emotional and the social. Roskilde University Press, Roskilde, Denmark.

Ison, R. L. 2007. Water politics: new plan-same old thinking. Available online at: http://newmatilda. com/home/printarticle.asp?ArticleID=2057.

Ison, R. L., and D. Russell, editors. 2000. Agricultural extension and rural development: breaking out of traditions. Cambridge University Press, Cambridge, UK.

Ison, R. L., P. Steyaert, P. P. Roggero, B. Hubert, and J. Jiggins, editors. 2004. Social learning for the integrated management and sustainable use of water at catchment scale. Final Report, SLIM, August 2004. Available online at: http://slim.open. ac.uk.

Ison, R. L., N. Röling, and D. Watson. 2007. Challenges to science and society in the sustainable management and use of water: investigating the role of social learning. Environmental Science and Policy, in press.

Kaïka, M., and B. Page. 2003. The EU Water Framework Directive: part 1. European policymaking and the changing topography of lobbying. European Environment 13(6):314-327.

Kaiika, M., and B. Page. 2003. The EU Water Framework Directive: part 2. Policy innovation and the shifting choreography of governance. European Environment 13(6):328-343.

Kallis, G., and D. Butler. 2001. The EU Water Framework Directive: measures and implications. Water Policy 3:125-142.

Lanz, K. 1998. Analysis of deficits of the Water Framework Directive and Greenpeace suggestions how to remedy them. WWF/EEB Workshop on Water Framework Directive, 22 October 1998, Brussels, Belgium. 
Larrère, C. 1997. Normes et savoirs. Pages 33-37 in C. Larrère and R. Larrère, editors. La crise environnementale. INRA, Paris, France.

Lascoumes, P., and J. P. Le Bourhis. 1998. Le bien commun comme construit territorial. Politix 42:37-66.

Lepart, J. 1997. La crise environnementale et les théories de l'équilibre en écologie. Pages 131-144 in C. Larrère and R. Larrère, editors. La crise environnementale. INRA, Paris, France.

Messner, F. 2006. Guest editorial. Environment and planning C: Government and Policy 24:159-167.

Muller, P. 1995. Les politiques publiques comme construction d'un rapport au monde. Pages 153-178 in A. Faure and G. Pollet, editors. La construction du sens dans les politiques publiques, débats autour de la notion de référentiel. L'Harmattan, Paris, France.

Müller, F. 1997. State-of-the-art in ecosystem theory. Ecological Modelling 100(1-3):135-161.

Noble, R., and I. Cowx. 2002. Development, evaluation and implementation of a standardised fish-based assessment method for the ecological status of European rivers: a contribution to the Water Framework Directive. Final Report. FAME: a project under the 5th Framework Program Energy, Environment, and Sustainable Management. Available online at: http://fame.boku.ac.at/.

Ollivier, G. 2004. An analytical understanding of the Water Framework Directive questioning its potential to enable sustainable management of water. SLIM Case Study Monograph 9. Available online at: http://slim.open.ac.uk.

Olson, P., and C. Folke. 2004. Adaptive comanagement for building resilience in socialecological xystems. Environmental Management 34 (1):75-90.

O'Neill, R. 2001. Is it time to bury the ecosystem concept? (With full military honors, of course !). Ecology 82(12):3275-3284.

Orr, P., Colvin, J. and D. King. 2007. Involving stakeholders in integrated river basin planning in England and Wales. Water Resource Management 21:331-349.
Ost, F. 2003. La nature hors la loi, l'écologie à l'épreuve du droit. La Découverte, Paris, France.

Quevauviller, P., P. Balabanis, C. Fragakis, M. Weydert, M. Oliver, A. Kaschl, G. Arnold, A. Kroll, L. Galbiati, J. M. Zaldivar, and G. Bidoglio. 2005. Science-policy integration needs in support of the implementation of the EU Water Framework Directive. Environmental Science and Policy 8(3):203-211.

Robertson, D., and R. Hull. 2001. Beyond biology: toward a more public ecology for conservation. Conservation Biology 15(4):970-985.

Röling, N. G., and M. A. E. Wagemakers.1998. Facilitating sustainable agriculture: participatory learning and adaptive management in times of environmental uncertainty. Cambridge University Press, Cambridge, UK.

Sabatier P. A., W. Focht, M. Lubell, Z. Trachtenberg, A. Vedlitz, and M. Matlock. 2005. Collaborative approaches to watershed management. Pages 3-21 in P. A. Sabatier, W. Focht, M. Lubell, Z. Trachtenberg, A. Vedlitz, and M. Matlock, editors. Swimming upstream: collaborative approaches to watershed management, American and Comparative Environmental Policy, The University of Chicago and MIT Press, Boston, Massachusetts, USA.

Social Learning for the Integrated Management and Sustainable Use of Water at Catchment Scale (SLIM), 2004. SLIM framework: social learning as a policy approach for sustainable use of water. [online] URL: http://slim.open.ac.uk

Snowden, D. 2002. Complex acts of knowingparadox and descriptive self-awareness. Journal of Knowledge Management 6(2):100-111.

Steyaert, P., and J. Jiggins. 2007. Governance of complex management situations through social learning: a synthesis of SLIM's lessons for research, policy and practice. Environmental Science and Policy, in press.

Steyaert, P., M. Barzman, J. P. Billaud, H. Brives, B. Hubert, G. Ollivier, and B. Roche. 2007. The role of knowledge and research in facilitating social learning among stakeholders in natural resources management in the French Atlantic coastal wetlands. Environmental Science and Policy, in press. 
Tippet, J., B. Searle, C. Pahl-Wostl, and Y. Rees. 2005. Social learning in public participation in river basin management: early findings from HarmoniCOP European case studies. Environmental Science and Policy 8(3):287-299.

Troper, M. 2000. Les contraintes juridiques dans la production des normes. Pages 27-46 in E. Serverin and A. Berthoud, editors. La production des normes entre etat et société civile. L'Harmattan, Paris, France.

Wasson, J., M. Tusseau-Vuillemin, V. Andréassian, C. Perrin, J. Faure, O. Barreteau, M. Bousquet, and B. Chastan. 2003. What kind of water models are needed for the implementation of the European Water Framework Directive? Examples from France. International Journal of River Basin Management 1(2):125-135. 
APPENDIX 1. Some key points of the Water Framework Directive (WFD).

"The WFD, as its name implies, establishes a framework providing for a common approach, and common objectives, principles, definitions, and basic measures" (WWF 2001:8). The main points of the framework can be developed around some key implementation tasks (Fig. 1):

- $\quad$ Each MS must set up 'River Basin Districts' (RBD), including river basins and other waters (coastal, ground, wetlands), and designate their 'Competent authorities'. RBD is the level to conceive, implement and control water management;

- Once 'water bodies' are characterized, key management issues must be identified and agreed at $\mathrm{RBD}$ level in order to reach environmental objectives defined through the notion of 'good water statuses'. This implies current water status assessment in regard of reference conditions or quality standards and economic analysis of water use. Active involvement of the public in building up management plans has to be encouraged;

- Programmes of measures and RBD management plans must include basic measures and supplementary ones if good status is to be achieved. Using economic analysis, the most cost effective combination of measures should be chosen to achieve good status. Water pricing policies must be developed applying various principles like cost recovery from primary water uses, including environmental costs;

- Monitoring networks of surface and ground-waters must be put in place to establish a coherent and comprehensive overview of water statuses. It must help assess and revise management plans, report progress to the EU and allow inter-calibration of RBDs' water statuses at EU level. 